UDC 541.64+543.226

\title{
INFLUENCE OF ALYUMOSILICATE CLAYS ON ECOLOGICAL CONDITION OF APSHERON LANDS
}

\section{Z.R.Agayeva, B.G.Mammadova*, E.M.Kazimova**, I.A.Talibli, S.G.Efendiyeva, Ch.M.Shabanova}

\author{
M.Nagiyev Institute of Catalysis and Inorganic Chemistry NAS of Azerbaijan \\ * Institute of Soil Science and Agrochemistry NAS of Azerbaijan \\ **Azerbaijan University of Architecture and Construction
}

agayeva-zenfira@mail.ru

Received 02.07.2019

Accepted 10.10.2019

\begin{abstract}
In the paper it is shown the results of research, focused on bentonite clay, deposited on the background of mineral fertilizers. This mineral is used to improve the ecological environment of the soil and increases the efficiency of mineral fertilizer application into it. Reducing soil degradation, in addition to improving plant productivity, bentonite has also a significant impact on the improvement of water, physical and agrochemical conditions of the soil and creates favorable conditions for improving plant growth and increased amount of phosphorus absorbed in the soil.
\end{abstract}

Keywords: gray-brown soil, rocks, montmorillonite, bentonite clay, eggplant.

doi

Increased industry development, intensive mining, individual branches of engineering and energy led to large-scale environmental pollution: air, water and soil. In this case soil, under the conditions of anthropogenic impact on the ecosphere, acts as a receiver of pollutants. The problem of cleaning the soil is one of the most important and at the same time it is difficult to resolve these problems. Despite the intensive efforts of scientists and entrepreneurs who conducted research in this area, this problem still has no concrete solution. This problem, which consists in cleaning the soil, including oil-polluted lands, and restoring its original structure, is still in demand and requires its own specific completion. Among the numerous proposed solutions aimed at eliminating these negative phenomena, a clear preference is given to the use of inorganic sorbents of natural origin. It should be noted that the territory of the Absheron Peninsula is exposed to the greatest pollution. At the same time, there is a need for relentless control over the oil contamination of the land and the Caspian oil and gas development sector, since this is directly related to the issues of industrial ecology and safety of life activity of living organisms. According to the monito- ring data, a significant amount of iron (up to $0.140-0.178 \mathrm{mg} / \mathrm{l})$, zinc $(0.126-0.166 \mathrm{mg} / \mathrm{l})$ and also several transboundary concentrations of heavy metals in the soil:iron $(10.6 \mathrm{~g} / \mathrm{kg})$ were detected in samples of the water of the Caspian Sea soil), nickel (up to $0.756 \mathrm{~g} / \mathrm{kg}$ of soil ) and copper (up to $0.068 \mathrm{~g} / \mathrm{kg}$ of soil ).

For the purpose to develop the above task, and test for profitability, we studied the clay rocks of the Absheron field as sorbents. In the study of the chemical and mineral composition of these rocks, it was found that this composition contains, unlike the bentonite rocks of other deposits (Dash-Salakhly, Hizi, Alibayramly, etc.), an insignificant amount of montmorillonite- $45 \%$. It was of scientific and practical interest for further use of the above clay minerals for the indicated purposes [1-2]. When selecting effective sorbents, it was also taken into account that natural clay minerals have the property of significant swelling during hydration [3-4]. At the same time, in the space limited for free swelling, in the presence of water, a dense gel is formed, which prevents further penetration of moisture and prevents its evaporation at high ambient temperatures. Such clay minerals, when added to the "light" soils as 
a meliorative sorbent, improve the soil structure and increase its fertility. The energy inhomogeneity of the surface of mineral particles leads to differences in the adsorption activity and selectivity of filling certain areas of the surface. On the surface of soil mineral particles, active sites form mosaic patterns from hydrophilic and hydrophobic sites where selective sorption takes place. Due to the irreversibility of the process, the soil loses its ability to retain moisture for vegetation, and the process of reproduction of biomass is disturbed. It was found that the application of clay minerals to the soil improves the water regime of dry suspended soil.

Various agrotechnical, meliorative measures are currently realized in Azerbaijan to improve the ecological environment of cultivated lands used in agriculture, to obtain clean and abundant crops from plants. One of the most important of these measures is the use of organic and mineral fertilizers as well as the use of natural soil improvement minerals. It is known that $75-85 \%$ of the needs of agricultural crops are covered by land resources. The main environmental problem is the replacement of nutrient deficiencies by mineral fertilizers. Therefore, it is of utmost importance to reduce soil degradation, as well as to increase the productivity of plants and use of non-traditional land improvers that have a significant impact on the water-physical and agro-biological regime of soil. Such non-traditional mineral resources can be represented by bentonite, seolite, perlite, tea and serpentinite. In recent studies, serpentinite from non-traditional soil improvers has been found in grass-grass and grass-gray soils in the Shirvan, Mil, Mugan and Garabagh plains of Kura, that was used under the plant. Currently, extensive research has been done on bentonite clay in many countries. It is of utmost importance that the bentonite clay containing calcium, magnesium, potassium, and several microelements is used to improve the physical, chemical and agrochemical properties of the soils [5]. The results of several studies have shown that the use of bentonite clay in different types of soil has had a good effect on the growth of agricultural crops [6].

It was determined the 3-years use of the Montmorillonite bentonite clay on the black soil by the fact that the bentonite clay improved the physical, chemical and agrochemical properties of the soil so that the vacuum productivity increased by $0.61 \mathrm{t} / \mathrm{h}$ or $16 \%$. Taking into account these studies, we aimed to explore the replication of the bentonite clay in our country in the agricultural sector.

\section{Results and discussion}

The general physical and chemical properties of the bentonite clay and the effects of bentonite clay on the agrochemical and chemical properties of the soil and the improvement of the ecological environment of the plant have been studied. The bentonite rocks are located in the territory of Dash Salahli village of Gazakh region and Gusdek on Absheron peninsula. Bentonite clay on the Absheron Peninsula is located at the depth of $5 \mathrm{~m}$ below the carbonate rocks in the Guzdek village. Bentonite clay was taken from that area. The aim of the research was to carry out experiments to improve soil ecological state, to increase the efficiency of mineral fertilizers to soil, and to explore the effects of bentonite clay on the background of mineral fertilizers on the background of plant-rich growth and the amount of monocular phosphorus in the soil to obtain cleaner crops. As the pilot object it was selected the experimental area of the Agricultural Institute located on the Absheron peninsula and soil samples were taken. Obtained initial data and coordinates of the slices is given in the Table 1 .

Field samples taken from the slaughterhouses of the Institute of Agriculture have been assigned field drainage and are listed in the Table 2 below.

Table 1. Characteristics of slices

\begin{tabular}{|l|l|l|l|}
\hline $\mathrm{k}-1$ & $40^{0} 31^{1} 49,4{ }^{\prime \prime} \mathrm{N}$ & $49^{0} 51^{1} 39,3$ "E & Poor nutrition of the grain $22-28 \mathrm{~cm}$. \\
\hline $\mathrm{k}-2$ & $40^{0} 31^{1} 48,5$ "N & $49^{0} 51^{1} 39,2$ "E & Average yield of grain is $32-37 \mathrm{~cm}$. \\
\hline $\mathrm{k}-3$ & $40^{0} 31^{1} 47,3$ "N & $49^{0} 51^{1} 42,2$ "E & Very poor output of grain is $15-20 \mathrm{~cm}$. \\
\hline $\mathrm{k}-4$ & $40^{0} 31^{1} 51.9^{\prime} \mathrm{N}$ & $49^{0} 51^{1} 54,6$ "E & The best output of the grain is $112-128 \mathrm{~cm}$. \\
\hline
\end{tabular}


Table 2. Ground-brown soil condition of the Absheron region

\begin{tabular}{|c|c|c|c|c|c|c|c|c|c|c|c|}
\hline $\mathrm{SN}$ & 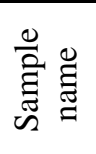 & $\begin{array}{l}\text { Depth } \\
\mathrm{cm}\end{array}$ & $\begin{array}{c}\text { Sample } \\
\mathrm{N}\end{array}$ & $\begin{array}{l}\text { Sample } \\
\text { empty } \\
\text { weight }\end{array}$ & $\begin{array}{l}\text { Sample } \\
\text { with } \\
\text { ground } \\
\text { weight }\end{array}$ & $\begin{array}{l}\text { Sample with } \\
\text { dry } \\
\text { ground } \\
\text { weight }\end{array}$ & loss & 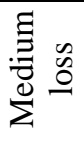 & $\begin{array}{l}\text { Clean } \\
\text { dry } \\
\text { land }\end{array}$ & $\sum_{E} \equiv$ & $\sum_{\Sigma}^{\Xi} \Xi \sigma^{\circ}$ \\
\hline 1 & 4 & $0-27$ & $\begin{array}{l}202 \\
016 \\
365\end{array}$ & $\begin{array}{l}22.5491 \\
21.6803 \\
21.9793\end{array}$ & $\begin{array}{l}36.5385 \\
36.2984 \\
36.2104\end{array}$ & $\begin{array}{l}35.2612 \\
34.7072 \\
34.6737\end{array}$ & $\begin{array}{l}1.28 \\
1.59 \\
1.54\end{array}$ & 1.47 & $\begin{array}{l}13.99 \\
14.62 \\
14.84\end{array}$ & 14.29 & 10.29 \\
\hline 2 & & $27-61$ & $\begin{array}{l}153 \\
345 \\
178 \\
\end{array}$ & $\begin{array}{l}21.2731 \\
22.3476 \\
21.9648 \\
\end{array}$ & $\begin{array}{l}34.7765 \\
33.0938 \\
33.5253 \\
\end{array}$ & $\begin{array}{l}33.1812 \\
31.6710 \\
32.2272 \\
\end{array}$ & $\begin{array}{l}1.60 \\
1.43 \\
1.30 \\
\end{array}$ & 1.45 & $\begin{array}{l}13.46 \\
10.75 \\
11.56 \\
\end{array}$ & 11.93 & 12.15 \\
\hline 3 & & $61-139$ & $\begin{array}{l}203 \\
384 \\
204 \\
\end{array}$ & $\begin{array}{l}21.8908 \\
21.8911 \\
22.1565 \\
\end{array}$ & $\begin{array}{l}30.3720 \\
32.8886 \\
33.7366 \\
\end{array}$ & $\begin{array}{l}29.3649 \\
31.7252 \\
32.3549 \\
\end{array}$ & $\begin{array}{l}1.01 \\
1.17 \\
1.39 \\
\end{array}$ & 1.19 & $\begin{array}{l}8.49 \\
11.0 \\
11.5 \\
\end{array}$ & 10.33 & 11.52 \\
\hline 4 & & $139-186$ & $\begin{array}{l}391 \\
218 \\
098 \\
\end{array}$ & $\begin{array}{l}22.3590 \\
22.7610 \\
20.9774 \\
\end{array}$ & $\begin{array}{l}35.4916 \\
37.4133 \\
33.4894 \\
\end{array}$ & $\begin{array}{l}34.0092 \\
35.7720 \\
32.1087 \\
\end{array}$ & $\begin{array}{l}1.49 \\
1.65 \\
1.29 \\
\end{array}$ & 1.48 & $\begin{array}{l}13.14 \\
14.66 \\
12.52 \\
\end{array}$ & 13.44 & 11.01 \\
\hline
\end{tabular}

Table 3. Compared with the bentonite clay superphosphate

\begin{tabular}{|l|l|l|l|l|l|}
\hline Practice scheme & 21.05 & 19.05 & 06.05 & 13.05 & 20.06 \\
\hline Control & 8.5 & 9.6 & 11.2 & 12.8 & 13.2 \\
\hline $100 \mathrm{qt}+$ back ground $(0.5 \mathrm{qs} / \mathrm{f})$ & 9.2 & 10.5 & 12.8 & 13.3 & 14.6 \\
\hline $100 \mathrm{qt}+$ back ground + 2q bentonite clay & 9.9 & 10.8 & 13.9 & 14.4 & 16.7 \\
\hline $100 \mathrm{qt}+2 \mathrm{q}$ bentonite clay & 8.1 & 9.5 & 12.1 & 12.9 & 13.9 \\
\hline
\end{tabular}

Soil samples taken from the experimental areas of the Institute of Agriculture were placed in containers for experiments in laboratory conditions and experiments under 2 repeated eggplant plants.

Practice scheme

1. Control option

2. Fon $(100 \mathrm{~kg}+0.5 \mathrm{~g}$.superphosphate)

3. Fon $+2 q$. bentonite clay

4. $100 \mathrm{~kg}$ of soil $+2 \mathrm{q}$. bentonite clay

The result of the study showed that, when serpentinite was deposited in the background of mineral fertilizers, it created a favorable waterresistant aggregate in the soil, reduces the soil's inflatable ability, improves dehydration, and also weakens serpentinite superphosphate to a hard-digested soil. Generally, the serpentinite in the background of mineral fertilizers is the nutritional elements used in the soil not only during the vegetation period, but even after the end of the vegetation period.

The results obtained from the experiments were analyzed as follows:

1. During the experiment, the height of the plants was monitored and measured once a week.

2. Determination of hygroscopic moisture in soil samples taken from plants at the end of the experiment

3. Determination of $\mathrm{pH}$
4. Determination of the amount of volatile phosphorus in the soil by the technique of migration.

The effect of the bentonite clay on the growth of the eggplant plant is given in Table 3. The height of the eggplant plant (in $\mathrm{cm}$ ).

The bentonite clay is clearly visible in the dynamics of plant growth. For example, if the size of the eggplant is $13.2 \mathrm{~cm}$ in the control version, the height of the eggplant has been $16.7 \mathrm{~cm}$ in the variant of the bentonite clay with the superphosphate. Comparison of plant height shows the favorable conditions for plant growth with the bentonite clay in the soil.

As shown by the results obtained, the bentonite clay superphosphate, as well as the option given alone, shows the amount of gentle cortex of the hygroscopic humidity. Thus, if the amount of hygroscopicity was $1.30 \%$ in the control variant, the bentonite clay with the superphosphate was $1.38 \%$, alone compared with $1.39 \%$ in the version. As seen from the results, the amount of $\mathrm{P}_{2} \mathrm{O}_{5}$ compared with the control version was $26.67 \mathrm{mg} / \mathrm{kg}$, with the superphosphate in the $2 \mathrm{q}$ bentonite clay version of $140.34 \mathrm{mg} / \mathrm{kg}$. The obtained results show the effect of bentonite clay on the amount of persistent phosphorus in the soil. The soil's ph alkaline environment has not changed much by the effect of the bentonite clay. 
Table 4. Determination of the gray-brown soil's hychroscopic moisture in the Absheron region

\begin{tabular}{|c|c|c|c|c|c|c|c|c|}
\hline $\begin{array}{c}\text { Experience } \\
\text { scheme }\end{array}$ & $\begin{array}{c}\text { Sample } \\
\mathrm{N}\end{array}$ & $\begin{array}{c}\text { Sample } \\
\text { empty } \\
\text { weight }\end{array}$ & $\begin{array}{c}\text { Sample } \\
\text { with } \\
\text { ground } \\
\text { weight }\end{array}$ & $\begin{array}{c}\text { Sample with } \\
\text { dry } \\
\text { ground } \\
\text { weight }\end{array}$ & loss & $\begin{array}{c}\text { Clean } \\
\text { dry } \\
\text { land }\end{array}$ & $\begin{array}{c}\% \\
\%\end{array}$ \\
\hline 1 & 348 & 22.9658 & 32.4244 & 32.3038 & 0.1207 & 9.3380 & 1.29 & 1.30 \\
\hline 2 & 329 & 23.1423 & 33.8218 & 33.6820 & 0.1398 & 10.5397 & 1.32 & \\
\hline 3 & 373 & 22.9000 & 34.2749 & 34.1308 & 0.1441 & 11.2308 & 1.28 & 1.28 \\
& 327 & 22.8659 & 34.7694 & 34.6167 & 0.1527 & 11.7508 & 1.29 & 1.38 \\
\hline 4 & 375 & 23.2277 & 34.0137 & 33.8667 & 0.1470 & 10.6390 & 1.38 \\
& 309 & 24.0046 & 33.7764 & 33.6428 & 0.1336 & 9.6382 & 1.38 & \\
\hline
\end{tabular}

\section{Conclusion}

It is important to reduce the soil degradation rate, as well as to increase the productivity of plants, as well as the use of non-traditional land improvers that have a significant impact on the water-physical and agro-ecosystems of the soil.

It has been learned that the bentonite clay consisting of calcium, magnesium, potassium and several micronutrients combined with superphosphate has a beneficial effect on the physico-chemical and agrochemical properties of the gray-brown soil of the Absheron region and the growth of the plant.

\section{References}

1. Altunin D.A. Vliianie glinovaniia na povyshenie plodorodiia peschanykh pochv. Dostizheniia nauki i tekhniki APK. 2001. № 12. S. 31-33.

2. Agaeva Z.R. Ispolzovanie glinistykh mineralov kak uvlazhnitelia pochv. Akademik M.Nağıyevin 110 illiyinə hısr olunmuş "Nağiyev günlərı" beynəlxalq elmi konfransın materialları, Bak1, 2018. S. 78.

3. Dzhafarova S.T., Gakhramanova E.B., Akhmedov M.M., Agaev A.I. Poluchenie katalizatorov v othode aliuminievogo proizvodstva dlia izvlecheniia sery. Himicheskaia promyshlennost segodnia, 2017. № 4. S. 26-33.

4. Məmmədova B.H., Mehdiyev H.C. C.Muğan düzü suvarılan boz-çəmən torpaqlarında mütəhərrik fosforun miqdarına serpentinitin 3 illik sonrakı təsiri Az.MEA Biologiya elmləri bölgəsi TAİ XI X cild, Bak1. Elm. 2011. S. 91-95.

5. Agafonov E.V., Hovanskii M.V. Izmenenie agrohimicheskikh svoistv chernozema obyknovennogo i urozhainosti sorgo pod vliianiem bentonita. Problemy agrohimii i ekologii. 2010. № 3. S. 3-6.

6. Dzhabarov E.E., Agaeva Z.R., Imanova N.A., Mamedova S.G., Mamedov U.A., Iagubov A.I. Issledovanie himiko-minerologicheskogo sostava modifitcirovannykh sloistykh aliumosilikatov. Tezisy docladov XIII Mezhdunarodnoi konferentcii "Problemy solvatatcii i kompleksoobrazovaniia v rastvorakh", Rossiia. g. Suzdal, 2018. S. 180-181.

\section{ALÜMOSILIKAT GILLORIN ABŞERON TORPAQLARININ EKOLOJI VӘZIYYYTINO TəSIRİ Z.R.Ağayeva, B.G.Məmmədova, E.M.Kazımova, İ.ə.Talıblı, S.G.Efendiyeva, Ç.M.Şabanova}

Məqalədə torpağın ekoloji mühitini sağlamlaşdırmaq, torpağa verilən mineral gübrələrin səmərəliliyini artırmaq üçün mineral gübrə fonunda torpağa verilən bentonit gilinin istifadə edilir. Torpaqların deqradasiyalaşmasının sürətini azaltmaq, eləcədə, bitkilərin məhsuldarlı̆̆ını artırmaqla yanaşı, həmçinin torpağın su-fiziki və aqrofiziki rejiminə də əhəmiyyətli təsir göstərir. Torpağın su-fiziki, aqrokimyəvi xüsusiyyətlərinə və ekoloji mühitin sağlamlaşmasına əlverişli şərait yaradır ki, bu da bitkilərin boy artımını və torpaqda mütəhhərrik fosforun miqdarını yaxşılaşdırır.

Açar sözlor: boz-qonur torpaq, süxur, montmorilonit, bentonit gili, badımcan bitkisi.

\section{ВЛИЯНИЕ АЛЮМОСИЛИКАТНЫХ ГЛИН НА ЭКОЛОГИЧЕСКОЕ СОСТОЯНИЕ АПШЕРОНСКИХ ЗЕМЕЛЬ}

\section{3.Р.Агаева, Б.Г.Мамедова, Э.М.Кязимова, И.А.Талыблы, С.Г.Эфендиева, Ч.М.Шабанова}

В статье с целью улучшения экологической среды почвы и повышения эффективности внесения в нее минеральных удобрений используется бентонитовая глина, нанесенная на фон минеральных удобрений. Снижение деградации почв, помимо повышения продуктивности растений, также оказывает существенное влияние на оздоровление водно-физического и агрохимическое состояние почвы и создает благоприятные условия для улучшения роста растений и количества поглощенного фосфора в почве.

Ключевые слова: серо-коричневая почва, горные породы, монтмориллонит, бентонитовая глина, сельскохозяйственная продукция баклажан. 